\title{
ERRATUM
}

\section{Erratum to: Low Carbohydrate Diets and Type 2 Diabetes: What is the Latest Evidence?}

Pamela Dyson

To view enhanced content go to www.diabetestherapy-open.com

Published online: October 30, 2015

(c) The Author(s) 2015. This article is published with open access at Springerlink.com

Erratum to: Diabetes Ther

DOI 10.1007/s13300-015-0136-9

The Disclosures section currently reads:

"Pamela Dyson declares that she has no conflict of interest."

The author wishes to make the following alteration:

"Pamela Dyson is CEO of The Oxford Health Alliance, a registered charity which has received funding from commercial sponsors including Novo Nordisk A/S and the PepsiCo Foundation. This paper was an invited review for which all publication charges were waived by the journal and no sponsorship was received."

Open Access. This article is distributed under the terms of the Creative Commons Attribution-NonCommercial 4.0 International License (http://creativecommons.org/licenses/ by-nc/4.0/), which permits any noncommercial use, distribution, and reproduction in any medium, provided appropriate credit to the original author(s) and the source, provide a link to the Creative Commons license, and indicate if changes were made.

The online version of the original article can be found under doi:10.1007/s13300-015-0136-9.

P. Dyson (ه)

Churchill Hospital, University of Oxford, OCDEM, Oxford, UK

e-mail: pamela.dyson@ocdem.ox.ac.uk 